\title{
Możliwości sterowania ilością wodoru dyfundującego w złączach spawanych
}

\author{
Possibilities of diffusible hydrogen control in welded joints
}

\section{Streszczenie}

W pracy omówiono metalurgiczne i technologiczne czynniki wpływające na obecność wodoru dyfundującego w stopiwie uzyskanym w środowisku powietrznym i pod wodą oraz podano metody obniżania jego ilości w złączach spawanych. Przedstawiono wyniki badań ukierunkowanych na określenie wpływu warunków i parametrów spawania na nawodorowanie stopiwa. Opracowano i podano zależności umożliwiające prognozowanie zawartości wodoru w złączach wykonanych pod wodą i na powietrzu najczęściej stosowanymi procesami spawania.

Słowa kluczowe: spawalność stali; wodór dyfundujący; spawanie pod wodą; spawanie mokre; metoda lokalnej komory suchej

\begin{abstract}
The paper discusses metallurgical and technological factors influencing the presence of diffusible hydrogen in deposited metal obtained in air and in underwater environment, and methods of reducing its amount in welded joints are described. The results of studies aimed at determining the influence of conditions and welding parameters on the hydrogenation of deposited metal are presented. Relationships enabling prediction of the hydrogen content in the joints made under water and in air with the most widely used welding processes have been developed and reported.
\end{abstract}

Keywords: weldability of steel; diffusible hydrogen; underwater welding; wet welding; local dry cavity method

\section{Wprowadzenie}

Najbardziej skuteczną metodą poprawy spawalności stali o podwyższonej i wysokiej wytrzymałości jest wyeliminowanie wpływu wodoru dyfundującego na złącza spawane. Pod pojęciem wodoru dyfundującego rozumie się mobilną w warunkach normalnych frakcję wodoru, która wniknęła do złącza podczas spawania [1,2]. Kontrolowanie ilości wodoru dyfundującego podczas i po zakończeniu spawania jest istotne, ponieważ jego obecność jest przyczyną formowania się pęcherzy gazowych, skłonności metalu do tworzenia pęknięć zimnych oraz innych zjawisk kruchości wodorowej. llość wodoru dyfundującego w złączu zależy przede wszystkim od metody spawania, warunków spawania (wilgotność i temperatura otoczenia), energii liniowej spawania (parametrów spawania), składu chemicznego, struktury materiału podstawowego i spoiwa oraz zabiegów technologicznych (suszenie materiałów dodatkowych, podgrzewanie

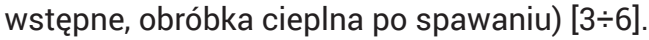

Większość sposobów obniżania zawartości wodoru dyfundującego w stopiwie bazuje na metodach metalurgicznych. Polegają one na modyfikacji składu chemicznego otulin i proszków w celu zmniejszenia ilości wodoru potencjalnego lub wprowadzeniu do nich składników, które wiążą wodór w związki trwałe w temperaturze spawania, ewentualnie ograniczają jego dyfuzję w metalu spoiny poprzez tworzenie pułapek wodorowych $[3,7]$. Drugą grupę działań zmierzających do zmniejszenia nawodorowania złączy stanowią zabiegi technologiczne ukierunkowane na obniżenie ilości wodoru potencjalnego (suszenie materiałów dodatkowych) albo modyfikację cyklu cieplnego spawania pozwalającą na wydłużenie czasu stygnięcia $t_{8 / 5}$ (podgrzewanie wstępne i obróbka cieplna po spawaniu) [3,5,8]. Stwierdzono również wpływ energii liniowej (parametrów spawania) na zawartość wodoru dyfundującego w stopiwie uzyskanym podczas spawania w środowisku powietrznym [9]. Jednostkowe badania dotyczyły wpływu spawania wielościegowego na nawodorowanie stopiwa pod wodą [10] i na powietrzu [11].

Wspomniane zależności zaliczają się do złożonych zagadnień wielowymiarowych, których kompleksowe ujęcie jest możliwe m.in. dzięki zastosowaniu statystycznych metod badawczych. Podejmowane są również próby wykorzystania do oceny ilości i rozkładu wodoru w złączach spawanych metod numerycznych $[12,13]$ oraz fizycznych $[14,15]$.

Celem pracy było podsumowanie stanu wiedzy na temat możliwości kontrolowania spawalności stali poprzez wykorzystanie różnych metod ograniczania ilości wodoru dyfundującego w stopiwie.

Dr inż. Dariusz Fydrych, dr inż. Grzegorz Rogalski, dr inż. Aleksandra Świerczyńska, dr hab. inż. Jerzy Łabanowski - Politechnika Gdańska.

Autor korespondencyjny/Corresponding author: darfydry@pg.edu.pl 


\section{Spawanie w środowisku powietrznym elektrodami otulonymi}

Spośród powszechnie stosowanych w przemyśle procesów spawalniczych najwyższe zawartości wodoru w złączach uzyskuje się podczas spawania elektrodami otulonymi, łukiem krytym pod topnikiem i drutami proszkowymi [17]. Zakres ilości wodoru dyfundującego w stopiwie charakterystyczny dla tych metod zależy głównie od gatunku stosowanych materiałów dodatkowych, a ściślej od rodzaju: otuliny, topnika i proszku. Jak wynika z zestawienia pokazanego w tablicy I do procesów niskowodorowych (H5) zalicza się głównie spawanie procesami, w których stosuje się spoiwa zasadowe.

Dotychczas przeprowadzone badania wykazały, że zmiany natężenia prądu spawania w zakresie $140 \div 190$ A nie powodują istotnych zmian $\mathrm{w}$ ilości wodoru generowanego przez spawanie elektrodą zasadową, natomiast przekroczenie tego zakresu powoduje zwiększenie zawartości wodoru w stopiwie przy jednoczesnym zmniejszeniu jego stężenia w przetopionym metalu (spoinie) wskutek przegrzania próbek [11]. Wzrost prędkości spawania powoduje zwiększenie zawartości wodoru w stopiwie, co można uzasadnić tym, że wraz ze wzrostem prędkości następuje zmniejszenie energii liniowej spawania, a więc zwiększenie prędkości stygnięcia i skrócenie czasu intensywnej dyfuzji wodoru. Ponadto prędkość spawania istotnie wpływa na udział metalu elektrody w spoinie. Wzrost napięcia łuku spawalniczego wpływa nieliniowo na nawodorowanie stopiwa, powodując początkowo wzrost, a następnie spadek ilości wodoru. Uzyskano niejednoznaczne wyniki dotyczące wpływu biegunowości spawania. Podczas opisanych powyżej badań nie zauważono wpływu tego czynnika na nawodorowanie próbek, natomiast podczas kolejnych zaobserwowano, że w całym zakresie natężeń prądu spawania stosowanych dla elektrody o średnicy $4 \mathrm{~mm}$ zawartość wodoru dyfundującego jest najniższa w przypadku spawania z biegunowością dodatnią [11].

Badania własne [20] przeprowadzone przy zastosowaniu planowania badań (wg planu Placketta-Burmana) pozwoliły na określenie istotności wpływu jedenastu czynników na zawartość wodoru dyfundującego w stopiwie elektrod o otulinie rutylowej: kąta pochylenia elektrody, stanu powierzchni próbki, temperatury podgrzania wstępnego, biegunowości prądu spawania, natężenia prądu spawania, szybkości chłodzenia próbki, stanu elektrody, czasu spawania, grubości próbki, czasu rozpoczęcia oznaczania wodoru oraz grubości otuliny. Czynniki wejściowe zostały wybrane spośród warunków przeprowadzenia pomiaru ilości wodoru dyfundującego w stopiwie oraz technologicznych parametrów spawania. Na rysunku 1 pokazano wyniki analizy statystycznej w postaci graficznej. Na jej podstawie opracowano równanie następującej postaci [20]:

$\mathrm{H}_{\mathrm{D}}=-260,81+0,15 \cdot \mathrm{Kel}+0,03 \cdot \mathrm{T}+2,27 \cdot \mathrm{p}+0,28 \cdot \mathrm{I}-0,21 \cdot \mathrm{Vc}-0,13 \cdot \mathrm{Se}+$

$+1,25 \cdot$ ts $-0,44 \cdot$ tp

gdzie:

$\mathrm{H}_{\mathrm{D}}$ - ilość wodoru dyfundującego w stopiwie oznaczona metodą glicerynową [ml/100 g],

Kel - kąt pochylenia elektrody $\left[^{\circ}\right]$,

$\mathrm{T}$ - temperatura podgrzania wstępnego $\left[{ }^{\circ} \mathrm{C}\right]$,

p - biegunowość prądu spawania,

I - natężenie prądu spawania [A],

Vc - szybkość chłodzenia [s],

Se - stan elektrody,

ts - czas spawania [s],

tp - czas rozpoczęcia oznaczania wodoru [min].

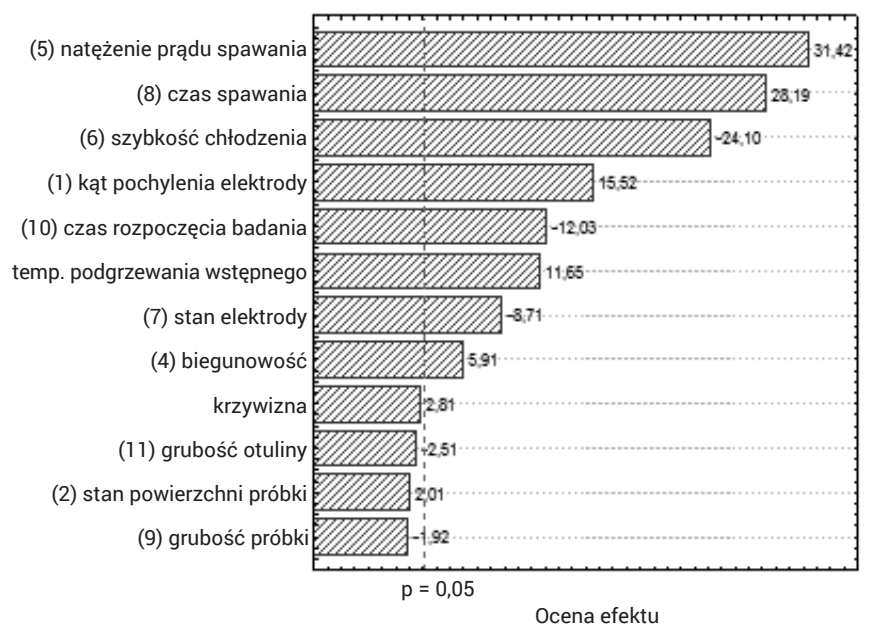

Rys. 1. Standaryzowany wykres efektów Pareto dla wyników badań wpływu warunków spawania elektrodami rutylowymi na nawodorowanie stopiwa [20]

Fig. 1. Standardized Pareto chart of effects for results of investigations of effect of rutile electrodes welding conditions on hydrogenation of deposited metal

Spośród czynników technologicznych statystycznie istotny wpływ wykazują: natężenie prądu spawania, czas spawania (prędkość spawania), kąt pochylenia elektrody, temperatura podgrzewania wstępnego oraz biegunowość prądu spawania. Należy zauważyć, że wszystkie te czynniki wpływają na zmianę wymiarów jeziorka spawalniczego. Niezależnie od określonej analitycznie istotności wpływu wzrost zawartości wodoru dyfundującego w stopiwie jest powodowany przez wzrost natężenia prądu, czasu spawania

Tablica I. Ilość wodoru dyfundującego w stopiwie uzyskanym z wybranych materiałów dodatkowych [3,16 $\div 19]$

Table I. Diffusible hydrogen content in deposited metal obtained from selected consumables

\begin{tabular}{|c|c|}
\hline Materiał dodatkowy & llość wodoru dyfundującego, ml/100 g \\
\hline Elektrody o otulinie zasadowej (111) & poniżej 5 \\
\hline Elektrody o otulinie rutylowej (111) & powyżej 30 \\
\hline Elektrody o otulinie celulozowej (111) & powyżej 40 \\
\hline Druty proszkowe zasadowe (136) & poniżej 5 \\
\hline Druty proszkowe rutylowe 10 \\
\hline Druty proszkowe metaliczne (138) & poniżej 5 \\
\hline Topnik zasadowy (121) & poniżej 10 \\
\hline
\end{tabular}


(spadku prędkości spawania), kąta pochylenia elektrody i temperatury podgrzewania wstępnego oraz grubości próbki. Dodatkowo zmiana biegunowości prądu z normalnej (DC-) na odwrotną (DC+) oraz zwiększenie grubości otuliny elektrody powoduje również wzrost zawartości wodoru. Natomiast pozostałe czynniki wpływają na wielkość wynikową w sposób przeciwny. Wynika z tego, że w celu zmniejszenia skłonności do tworzenia pęknięć zimnych należy wykonywać złącze z maksymalnym dopuszczalnym dla danej elektrody natężeniem prądu spawania i niską prędkością. Jednoczesne spełnienie obydwu tych warunków prowadzi do uzyskiwania wysokich wartości energii liniowej, co teoretycznie jest korzystne ze względu na wydłużenie czasu stygnięcia próbki, a więc również czasu wzmożonej dyfuzji wodoru ze złącza [20].

Ilość wodoru dyfundującego w złączach spawanych zmienia się w stopniu zależnym od zastosowanej technologii, a więc nie tylko od parametrów i materiałów dodatkowych, lecz również techniki spawania, która wpływa na objętość jeziorka i warunki stygnięcia złącza: kąta pochylenia elektrody, szerokości ściegu zakosowego i ilości ściegów. W przypadku spawania wielościegowego stwierdzono, że wzrost ilości ściegów skutkuje zmniejszeniem zawartości wodoru dyfundującego w stopiwie [11]. Zgodne z tym wyniki uzyskano podczas badań technologii właściwej dla wykonywania złączy poprzecznych rurociągów przesyłowych. Wzrost ilości ściegów z 1 do 4 spowodował zmniejszenie zawartości wodoru dyfundującego w stopiwie z 40,26 do 11,75 ml/100 g podczas spawania elektrodami celulozowymi i zasadowymi [21] oraz z 35,67 do 18,40 ml/100 g przy wykorzystaniu elektrod rutylowych [22].

\section{Spawanie w środowisku powietrznym drutem proszkowym}

Ponieważ udział zastosowania procesów wykorzystujących jako spoiwo drut proszkowy systematycznie się

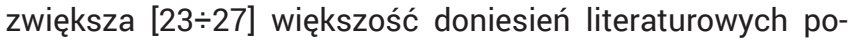
święconych jest zależnościom między warunkami i parametrami a nawodorowaniem złączy wykonanych tymi metodami $[5,9,17,28 \div 31]$. Z przedstawionych w nich analiz eksperymentalnych i analitycznych wynika, że wpływ na rozważane zjawisko mają następujące czynniki: natężenie prądu spawania, napięcie łuku, prędkość spawania, długość wolnego wylotu, natężenie przepływu gazu osłonowego, skład chemiczny gazu osłonowego oraz warunki otoczenia: ciśnienie, temperatura oraz wilgotność powietrza [5,17]. Doniesienia te znajdują potwierdzenie w wynikach badań własnych [32]. Na podstawie badań zrealizowanych z zastosowaniem planu Placketta-Burmana ustalono, że spadek ilości wodoru wyekstrahowanego z napoin próbnych wynikał ze wzrostu prędkości podawania drutu, prędkości spawania, długości wolnego wylotu oraz natężenia przepływu gazu osłonowego. Natomiast wzrost napięcia łuku powodował skutek przeciwny. Równanie opisujące te zależności ma następującą postać [32]:

$H_{D}=3,131+0,603 \cdot U-0,016 \cdot V d-0,021 \cdot V w-0,119 \cdot L-0,292 \cdot w g$

gdzie:

$\mathrm{H}_{\mathrm{D}}$ - ilość wodoru dyfundującego w stopiwie oznaczona metodą glicerynową [ml/100 g],

$\mathrm{U}$ - napięcie łuku [V],

$\mathrm{Vd}$ - prędkość podawania drutu [m/min],

Vw - prędkość spawania [cm/min],

L - długość wolnego wylotu drutu elektrodowego [mm], wg - natężenie przepływu gazu osłonowego [l/min].

\section{Spawanie w środowisku wodnym elektrodami otulonymi}

Wpływ warunków spawania na nawodorowanie stopiwa jest szczególnie uwidoczniony podczas spawania pod wodą, ponieważ środowisko spawania stanowi dodatkowe źródło wodoru [33]. Z uwagi na fakt, iż nie ma w tych warunkach możliwości ograniczenia zawartości wodoru dyfundującego w złączu do poziomu procesów niskowodorowych, przeniesienie spawania pod wodę powoduje istotny wzrost skłonności stali do pękania zimnego [34,35]. Z analizy literatury wynika, że ilość wodoru dyfundującego w złączu zależy od ciśnienia wody, a więc od głębokości spawania [36], natomiast nie jest uzależniona od rodzaju warstwy ochronnej lub jej braku ani od stopnia zawilgocenia otuliny [37], a w przypadku wzrostu energii liniowej zawartość wodoru się zmniejsza [38]. Również wyniki badań własnych wskazują na to, że stosowanie powłoki wodoodpornej nie powoduje istotnej zmiany nawodorowania stopiwa [37]. Kompleksowe ujęcie zagadnienia wraz z ilościowym określeniem istotności wpływu i relacji między czynnikami odpowiedzialnymi za zmiany stopnia nawodorowania stopiwa zaproponowano w publikacjach [37,39]. Na etapie badań rozpoznawczych [37] stwierdzono, że wzrost zasolenia wody i spawanie z biegunowością dodatnią powoduje zmniejszenie zawartości wodoru dyfundującego w stopiwie, natomiast zanieczyszczenie elektrody węglowodorami i wzrost natężenia prądu spawania wpływają na wzrost jego ilości. Wyniki te uszczegółowiono w pracy [39] ustalając, że wzrost natężenia prądu spawania, zasolenia wody i spawanie z biegunowością dodatnią powoduje zwiększenie zawartości wodoru w stopiwie. Zastosowanie metody technologicznej umożliwia obniżenie nawodorowania stopiwa elektrod rutylowych do poziomu właściwego dla spawania w środowisku powietrznym (poniżej $40 \mathrm{ml} / 100 \mathrm{~g}$ ). Opracowano również równania umożliwiające prognozowanie ilości wodoru dyfundującego w stopiwie [39]:

$H_{D}=-849,202+0,186 \cdot 1+0,166 \cdot s+8,422 \cdot p$

gdzie:

$\mathrm{H}_{\mathrm{D}}$ - ilość wodoru dyfundującego w stopiwie oznaczona metodą rtęciową [ml/100 g],

I - natężenie prądu spawania [A],

s - zasolenie wody [\%],

$\mathrm{p}$ - biegunowość prądu spawania.

Biegunowość prądu spawania jest czynnikiem kategoryzacyjnym, więc dla konkretnego przypadku (DC- albo DC+) przelicza się wartość ostatniego członu i dodaje do stałej równania [39].

\section{Spawanie w środowisku wodnym drutem proszkowym}

W ostatnich latach duże znaczenie praktyczne, poza tradycyjnie stosowanym pod wodą procesem spawania elektrodami otulonymi, zyskuje spawanie mokre drutem proszkowym samoosłonowym [40 $\div 42]$. Zgodnie z wykresami pokazanymi na rysunkach 2 i 3 wzrost napięcia łuku powoduje wzrost zawartości wodoru dyfundującego w stopiwie, natomiast zwiększanie natężenia prądu spawania lub zasolenia wody spadek jego ilości [43].

Na podstawie badań własnych [44] stwierdzono, że w zależności od warunków spawanie mokre drutem samoosłonowym generuje ilość wodoru dyfundującego od 25,85 do $44,12 \mathrm{ml} / 100 \mathrm{~g}$. Największy wpływ na zawartość wodoru 
dyfundującego w stopiwie ma długość wolnego wylotu, w dalszej kolejności prędkość spawania, zasolenie wody, napięcie łuku oraz natężenie prądu spawania. Wzrost wartości czynników powodujących zwiększenie objętości

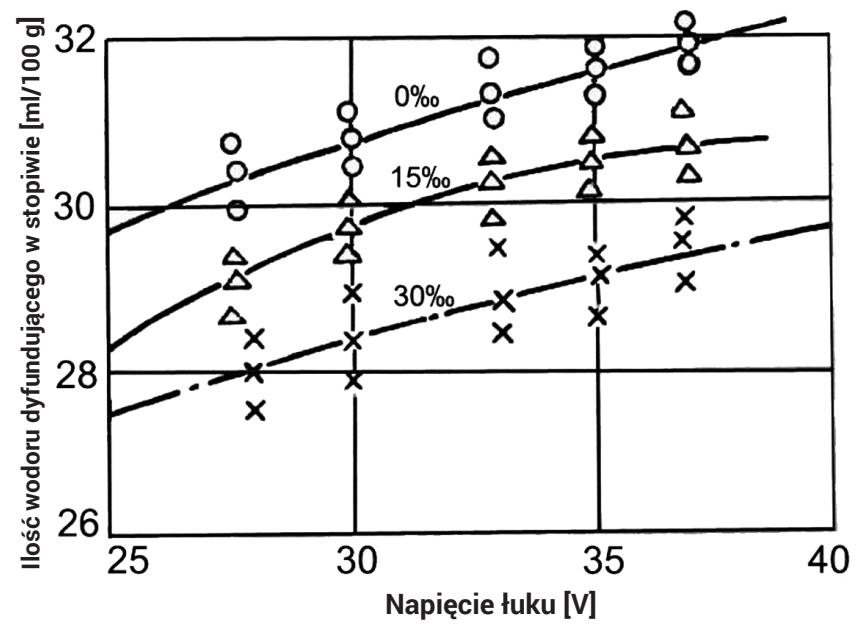

Rys. 2. Wpływ napięcia łuku przy spawaniu mokrym drutem proszkowym samoosłonowym na zawartość wodoru dyfundującego w stopiwie [43]

Fig. 2. Effect of arc voltage in underwater wet self-shielded flux cored arc welding on diffusible hydrogen content in deposited metal

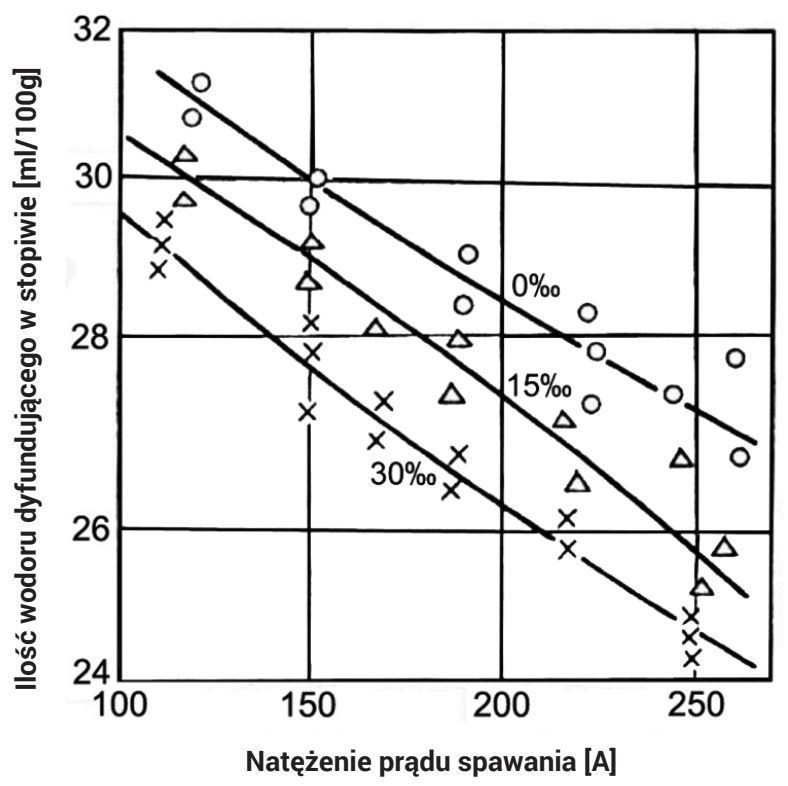

Rys. 3. Wpływ natężenia prądu spawania mokrego drutem proszkowym samoosłonowym na zawartość wodoru dyfundującego w stopiwie [43]

Fig. 3. Effect of welding current in underwater wet self-shielded flux cored arc welding on diffusible hydrogen content in deposited metal jeziorka spowodował spadek ilości wodoru dyfundującego w stopiwie. Nawodorowanie stopiwa dla znanych warunków spawania pod wodą drutem samoosłonowym można obliczyć z zależności [44]:

$H_{D}=66,14+0,63 \cdot L-0,05 \cdot I-1,55 \cdot U+18,85 \cdot V w-0,13 \cdot s$

gdzie:

$\mathrm{H}_{\mathrm{D}}$ - ilość wodoru dyfundującego w stopiwie oznaczona metodą glicerynową [ml/100 g],

$\mathrm{L}$ - długość wolnego wylotu [mm],

I - natężenie prądu spawania $[A]$,

$\mathrm{U}$ - napięcie łuku [V],

Vw - prędkość spawania [cm/s],

s - zasolenie wody [\%].

\section{Spawanie w środowisku wodnym metodą lokalnej komory suchej}

Spawanie metodą lokalnej komory suchej stwarza warunki mniej sprzyjające nawodorowaniu stopiwa, ponieważ obszar spawania jest odizolowany od wody przez komorę, do której doprowadza się gaz osłonowy [45,46]. Jednak niezależnie od zastosowanego rodzaju gazu osłonowego, we wnętrzu komory znajduje się pewna ilość pary wodnej, której źródłem jest tzw. mokry stan powierzchni, wynikający z niedokładnego osuszenia materiału spawanego $[46,47]$. W konsekwencji ilość wodoru dyfundującego w stopiwie uzyskanym tą metodą osiąga wartości nawet do $20 \mathrm{ml} / 100 \mathrm{~g}$ [48]. W autorskiej pracy [46] zbadano ilościowo wpływ czynników technologicznych i konstrukcyjnych na ilość wodoru dyfundującego w stopiwie ustalając, że wzrost napięcia łuku, zasolenia wody inatężenia prądu spawania wpływa na wzrost nawodorowania złącza, natomiast odwrotny skutek wywiera wzrost długości wolnego wylotu oraz zwiększenie ilości zwojów opaski elastycznej. Wyznaczono również równanie opisujące rozpatrywane zagadnienie [46]:

$\mathrm{H}_{\mathrm{D}}=8,15-1,72 \cdot \mathrm{i}-0,24 \cdot \mathrm{L}+0,02 \cdot \mathrm{I}+0,39 \cdot \mathrm{U}+4,72 \cdot \mathrm{Vw}+0,27 \cdot \mathrm{s}+$ $-0,18 \cdot w g$

gdzie:

$\mathrm{H}_{\mathrm{D}}$ - ilość wodoru dyfundującego w stopiwie oznaczona metodą glicerynową [ml/100 g],

i - ilość zwojów opaski elastycznej [-],

$\mathrm{L}$ - długość wolnego wylotu drutu elektrodowego [mm],

I - natężenie prądu spawania $[A]$,

$\mathrm{U}$ - napięcie łuku [V],

Vw - prędkość spawania [cm/s],

s - zasolenie wody [\%],

wg - natężenie przepływu gazu osłonowego [l/min].

\section{Podsumowanie}

Oddziaływanie wodoru na własności i jakość złączy spawanych zostało zaobserwowane kilkadziesiąt lat temu [49]

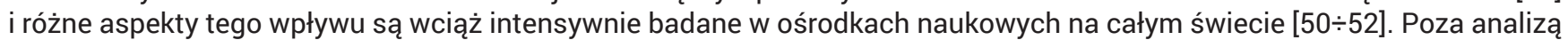
mechanizmów wszystkich form niszczenia wodorowego materiałów spawalnych rozpatruje się także inne zagadnienia wynikające z obecności wodoru w złączach spajanych. Następuje m.in. intensywny rozwój metod pomiarowych oraz uaktualnianie i ujednolicanie przepisów w tym zakresie [53].

Interesującymi kierunkami badań, których wyniki pośrednio dotyczą kontrolowania nawodorowania stopiwa, są próby ilościowego opisu źródeł wodoru, a także mechanizmów regulujących jego wnikanie do jeziorka spawalniczego i w dalszej kolejności do innych obszarów tworzącego się złącza oraz ekstrakcję z metalu po zakończeniu spawania. Natomiast bezpośredni wpływ na te aspekty jakości złączy spawanych, które zależą od obecności w nich wodoru, mają warunki przechowywania materiałów dodatkowych do spawania [8,28,54]. 
W przypadku wszystkich opisanych metod spawania ilość wodoru dyfundującego w stopiwie jest silnie uzależniona od parametrów spawania wpływających na wymiary jeziorka spawalniczego, od których zależy intensywność wymiany gazowej między otoczeniem a ciekłym metalem. Przedstawione wyniki potwierdzają również w ogólności pogląd, że parametry elektryczne spawania wpływają na ilość wodoru dyfundującego w stopiwie pośrednio: zmieniając charakter przenoszenia metalu w łuku [30,43]. Zmiany wartości parametrów spawania wpływają na rozmiar kropli metalu w łuku, co poprzez stosunek pola powierzchni do objętości metalu wpływa na kinetykę reakcji utleniania stopiwa. W konsekwencji następują zmiany stopnia nawodorowania złącza wynikające z odwrotnie proporcjonalnej zależności między zawartością tlenu i wodoru w obszarze spawania.

Poza informacjami o charakterze podstawowym tłumaczącymi mechanizmy i relacje zachodzące między warunkami i parametrami spawania, a ilością wodoru dyfundującego w stopiwie (m.in. liniowość wpływu czynników niezależnych) przeprowadzone dotychczas badania pozwoliły na opracowanie wykresów i równań stanowiących narzędzie inżynierskie umożliwiające predykcję stopnia nawodorowania stopiwa w określonych warunkach spawania. Zakres stosowania uzyskanych zależności jest ograniczony do zakresu zmienności czynników badanych oraz konieczności zapewnienia stabilności jarzenia się łuku i wykonania złączy spełniających określone kryteria akceptacji dotyczące m.in. poziomów jakości złączy spawanych, oraz właściwości wytrzymałościowych.

\section{Literatura}

[1] Fydrych D., Łabanowski J.: An experimental study of high-hydrogen weIding processes, Revista de Metalurgia 51(4), 2015.

[2] Fydrych D., Łabanowski J.: Determining diffusible hydrogen amounts using the mercury method, Welding International 26(9), 2012.

[3] Tasak E., Ziewiec A.: Spawalność materiałów konstrukcyjnych: Spawalność stali, Wydawnictwo JAK, Kraków 2009.

[4] Harwig D.D., Longenecker D.P., Cruz J.H.: Effects of welding parameters and electrode atmospheric exposure on the diffusible hydrogen content of gas flux cored arc welds, Welding Journal 78(9), 1999

[5] Świerczyńska A.: Effect of technological factors on diffusing hydrogen content in the weld deposit of rutile flux-cored wires, Institute of Welding Bulletin 57(5), 2013.

[6] Fydrych D., Tomków J., Świerczyńska A.: Determination of diffusible hydrogen content in the deposited metal of rutile electrodes by the glycerin method, Metallurgy and Foundry Engineering 39(1), 2013.

[7] Rowe M.D., Liu S., Reynolds T.J.: The effect of ferro-alloy additions and depth on the quality of underwater wet welds, Welding Journal 81(8), 2002

[8] Fydrych D., Świerczyńska A., Landowski M.: Preliminary studies of seamless flux cored wires stored in extreme conditions, Metallurgy and Foundry Engineering 40(4), 2016.

[9] White D., Pollard G., Gee R.: The effect of welding parameters on diffusible hydrogen levels in cored wire welding, Welding \& Metal Fabrication 6, 1992.

[10] Hoffmeister H., Kuster K.: Process variables and properties of underwater wet shielded metal arc laboratory welds, Proceedings of the International Conference „Underwater Welding”, Trondheim, Norway 1983.

[11] Pokhodnya I.K.: Metallurgy of arc welding. Naukowa Dumka, Kiev 2004.

[12] Jemblie L., Olden V., Akselsen O.M.: A coupled diffusion and cohesive zone modelling approach for numerically assessing hydrogen embrittlement of steel structures, International Journal of Hydrogen Energy 42(16), 2017.

[13] Karkhin V.A., Levchenko A.M.: Computer-aided determination of diffusible hydrogen in deposited weld metal, Welding in the World 52(3-4), 2008.

[14] Pessoa E.C.P., Bracarense A.Q., Zica E.M., Liu S., Perez-Guerrero F.: Porosity variation along multipass underwater wet welds and its influence on mechanical properties, Journal of Materials Processing Technology 179(1), 2006.

[15] Портнов О.М., Максимов С.Ю.: Численное моделирование абсорбции газов наплавленным металлом при подводной мокрой сварке Автоматическая сварка 7, 2006.

[16] Fydrych D., Łabanowski J., Rogalski G.: Weldability of high strength steels in wet welding conditions, Polish Maritime Research 20(2), 2013

[17] Pitrun M., Nolan D., Dunne D.: Diffusible hydrogen content in rutile flux cored arc welds as a function of the welding parameters, Welding in the World 48(1-2), 2004.

[18] Lee H.W., Kang S.W.: A study on transverse weld cracks in $50 \mathrm{~mm}$ thick steel plate with SAW process, Quarterly Journal of the Japan Welding Society 15(4), 1997.

[19] Atkins G., Thiessen D., Nissley N., Adonyi Y.: Welding process effects in weldability testing of steels, Welding Journal 81(4), 2002.

[20] Świerczyńska A., Fydrych D., Łabanowski J.: The effect of welding conditions on diffusible hydrogen content in deposited metal, Solid State Phenomena 183, 2012.

[21] Fydrych D., Malinowski P., Świerczyńska A., Rogalski, G.: Pomiary ilości wodoru dyfundującego w stopiwie elektrod celulozowych i zasadowych, Przegląd Spawalnictwa 86(8), 2014

[22] Fydrych D., Świerczyńska A., Rogalski G.: Diffusible hydrogen content in the deposited metal of multilayer welded joints, Metallurgy and Foundry Engineering 40(4), 2014.

[23] Chmielewski T., Węglowski M.: Analiza rynku spawalniczego w Polsce pod względem sprzedaży urządzeń oraz materiałów spawalniczych, Przegląd Spawalnictwa 82(6), 2010
[24] Górka J., Stano S.: Własności i struktura złączy spawanych hybrydowo HLAW (wiązka laserowa-FCAW) stali obrabianej termomechanicznie S700MC, Przegląd Spawalnictwa 87(5), 2015.

[25] Wojnarowski K., Chmielewski T., Golański D., Węglowski M.: Wpływ mechanizacji spawania złączy rurowych metodą FCAW (136) na właściwości procesu, Przegląd Spawalnictwa 87(5), 2015.

[26] Bęczkowski R.: Wybrane zagadnienia stosowania odpornych na zużycie płyt w przemyśle wydobywczym, Przegląd Spawalnictwa 89(5), 2017.

[27] Rogalski G., Fydrych D., Łabanowski J.: Ocena możliwości spawania pod wodą drutem proszkowym metodą lokalnej komory suchej, Biuletyn Instytutu Spawalnictwa w Gliwicach 56(5), 2012.

[28] Mee van der V.: Effect of atmospheric storage condition on weld metal diffusible hydrogen content of gas shielded cored wires. Doc. IIW II-143701/IIA-082-01.

[29] Kiefer J.H.: Effects of moisture contamination and welding parameters on diffusible hydrogen, Welding Journal 75(5), 1996.

[30] Bracarense A.Q., Lacerada de Souza R., de Souza Costa M.C.M., Faria P.E., Liu S.: Welding current effect on diffusible hydrogen content in flux cored arc weld metal, Journal of the Brazilian Society of Mechanical Sciences 24(4), 2002.

[31] Michael S., Sierdzinski M., Ferree E.: New flux cored wires control diffusible hydrogen levels, Welding Journal 77(2), 1998.

[32] Fydrych D., Świerczyńska A., Tomków J.: Diffusible hydrogen control in flux cored arc welding process, Key Engineering Materials 597, 2014.

[33] Fydrych D., Rogalski G., Łabanowski J.: Problems of underwater welding of higher-strength low alloy steels, Institute of Welding Bulletin 58(5), 2014

[34] Fydrych D., Świerczyńska A., Rogalski G., Łabanowski J.: Temper bead welding of S420G2+ M steel in water environment, Advances in Materials Science 16(4), 2016

[35] Łabanowski J., Prokop-Strzelczyńska K., Rogalski G., Fydrych D.: The effect of wet underwater welding on cold cracking susceptibility of duplex stainless steel, Advances in Materials Science 16(2), 2016.

[36] Ando S., Asahina T.: A study on the metallurgical properties of steel welds with underwater gravity welding, Proceedings of the International Conference "Underwater Welding", Trondheim, Norway 1983.

[37] Fydrych D., Rogalski G.: Wpływ warunków spawania mokrego elektrodą otuloną na zawartość wodoru dyfundującego w stopiwie, Przegląd Spawalnictwa 80(2), 2008.

[38] Hoffmeister H., Kuster K.: Process variables and properties of underwater wet shielded metal arc laboratory welds. Proceedings of the International Conference "Underwater Welding”, Trondheim, Norway 1983.

[39] Fydrych D., Świerczyńska A., Rogalski G.: Effect of underwater wet weIding conditions on the diffusible hydrogen content in deposited metal, Metallurgia Italiana 11/12, 2015.

[40] Wang J., Sun Q., Wu L., Liu Y., Teng J., Feng, J.: Effect of ultrasonic vibration on microstructural evolution and mechanical properties of underwater wet welding joint, Journal of Materials Processing Technology 246, 2017.

[41] Li H.L., Liu D., Yan Y.T., Guo N., Feng J. C.: Microstructural characteristics and mechanical properties of underwater wet flux-cored wire welded $316 \mathrm{~L}$ stainless steel joints, Journal of Materials Processing Technology 238, 2016.

[42] Jia C., Zhang T., Maksimov S.Y., Yuan X.: Spectroscopic analysis of the arc plasma of underwater wet flux-cored arc welding, Journal of Materials Processing Technology 213(8), 2013.

[43] Kononenko V.Ya.: Effect of water salinity and mechanized underwater welding parameters on hydrogen and oxygen content of weld metal, Proceedings of the International Conference "Welding Under Extreme Conditions", Helsinki, Finland 1989.

[44] Świerczyńska A., Fydrych D., Rogalski G.: Diffusible hydrogen management in underwater wet self-shielded flux cored arc welding, International Journal of Hydrogen Energy 42(9), 2017. 
[45] Rogalski G., Łabanowski J., Fydrych D., Tomków J.: Bead-on-plate weIding on S235JR steel by underwater local dry chamber process, Polish Maritime Research 21(2), 2014.

[46] Fydrych D., Rogalski G.: Effect of underwater local cavity welding method conditions on diffusible hydrogen content in deposited metal, Welding International 27(3), 2013.

[47] Fydrych D., Rogalski G., Prokop K.: Badania warunków spawania pod wodą metodą lokalnej komory suchej, Przegląd Spawalnictwa 86(9), 2014.

[48] Fydrych D.: Wpływ warunków spawania na skłonność do tworzenia pęknięć zimnych przy spawaniu pod wodą. Praca doktorska, Politechnika Gdańska, Gdańsk 2005.

[49] Stern I.L., Kalinsky J., Fenton E.A.: Gas evolution from weld metal deposits, Welding Journal 28(9), 1949.
[50] Cairney J.: Atoms on the move-finding the hydrogen, Science 355(6330), 2017.

[51] Chen Y.S., Haley D., Gerstl S.S.A., London A.J., Sweeney F., Wepf R.A et al.: Direct observation of individual hydrogen atoms at trapping sites in a ferritic steel, Science 355(6330), 2017.

[52] Paxton A.T., Sutton A.P., Finnis M.W.: The challenges of hydrogen and metals, Philosophical Transactions of the Royal Society A 375(2098), 2017.

[53] Padhy G.K., Ramasubbu V., Albert S.K., Murugesan N., Ramesh C.: Hot extraction of diffusible hydrogen and its measurement using a hydrogen sensor, Welding in the World 56(7), 2012.

[54] Reisgen U., Willms K., Wieland S.: Influence of storage conditions on aluminum 4043A welding wires, Welding Journal 96(6), 2017. 